\title{
KINERJA KAMBING SABURAI YANG DIPELIHARA PETERNAK DI DESA GISTING ATAS KECAMATAN GISTING KABUPATEN TANGGAMUS
}

\author{
Saburai Goat Performance Reared by Farmer in Gisting Atas Village Gisting District Tanggamus \\ Regency
}

\author{
Ananta Maulana Fikri, Kusuma Adhianto, Ali Husni, dan Arif Qisthon
}

Department of Animal Husbandry, Faculty of Agriculture, University of Lampung Soemantri Brojonegoro No.1 Gedong Meneng Bandar Lampung 35145 e-mail : anantamaulanafikri@gmail.com

\begin{abstract}
The aim of this research was to determine the performance of Saburai goats reared by farmer in Gisting Atas Village, Gisting District, Tanggamus Regency. These research was conducted in June until August 2019 in Saburai goat breeding group at Gisting Atas Village, Gisting District, Tanggamus Regency, Lampung Province. The research used 14 farmers as respondents and their Saburai goats with various age levels, namely at kid, young goat, and dam. The research method used was direct interviews and observations in the field which include collecting farmer profile data, while livestock performance data was observed using data recording of the animal. The data was analyzed by descriptive analysis. The results showed that $100 \%$ of farmers motivation was to increase their income. Each farmer had 10 tail of goat in average. The average performance of goats were kidding intervals of $310.43 \pm 49.70$ days, litter size of $1.88 \pm 0.40$ tails, postpartum oestrus of $61.58 \pm 9.72$ days, postpartum mating of $149.11 \pm 51,19$ days, birth weight of $2.83 \pm 0.11 \mathrm{~kg}$, weaning weight of $11.28 \pm 1.36 \mathrm{~kg}$, and yearling weight of $25.98 \pm 2.93 \mathrm{~kg}$. The Conclusion of this research was that the performance of Saburai goats that are kept by farmers has decreased if compared with performance of many years before current research.
\end{abstract}

Keywords : Gisting Atas, Performance, Saburai Goat, Tanggamus Regency.

\section{ABSTRAK}

Penelitian ini bertujuan untuk mengetahui kinerja kambing Saburai yang dipelihara oleh peternak pembibitan di Desa Gisting Atas, Kecamatan Gisting, Kabupaten Tanggamus. Penelitian ini dilaksanakan pada Juni sampai Agustus 2019 di kelompok peternak kambing Saburai Desa Gisting Atas, Kecamatan Gisting, Kabupaten Tanggamus, Lampung. Materi penelitian adalah 14 peternak sebagai responden dan kambing Saburai pada berbagai tingkatan umur, baik cempe, induk maupun kambing muda. Metode penelitian yang digunakan adalah wawancara dan pengamatan langsung di lapangan yang meliputi pengambilan data profil peternak, sedangkan data kinerja ternak diamati dengan menggunakan kartu catatan ternak (recording). Data dianalisis secara deskriptif. Hasil penelitian menunjukkan bahwa $100 \%$ peternak menyatakan tujuan beternak adalah menambah pendapatan. Rata-rata jumlah kepemilikan ternak kambing sebanyak 10 ekor. Rata-rata kinerja kambing adalah sebagai berikut, yaitu meliputi interval kelahiran $310,43 \pm 49,70$ hari, litter size 1,88 $\pm 0,40$ ekor, post partum estrus $61,58 \pm 9,72$ hari, post

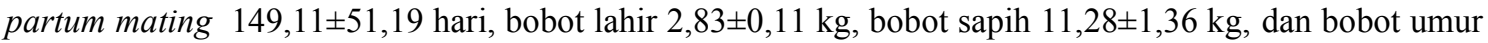
1 tahun $25,98 \pm 2,93 \mathrm{~kg}$. Berdasarkan hasil penelitian ini dapat disimpulkan bahwa kinerja kambing Saburai yang dipelihara peternak mengalami penurunan bila dibandingkan dengan tahun-tahun sebelumnya.

Kata Kunci : Gisting Atas, Kinerja, Kambing Saburai, Kabupaten Tanggamus.

\section{PENDAHULUAN}

Jumlah penduduk Indonesia mengalami peningkatan setiap tahun, pada 2017 mencapai 262 juta jiwa, sedangkan pada 2018 mencapai 265 juta jiwa (Badan Pusat Statistik, 2013). Hal tersebut berdampak pada meningkatnya permintaan pangan sumber protein hewani yang berasal dari ternak. Untuk memenuhi kebutuhan protein hewani diantaranya berasal dari ternak kambing sehingga perlu meningkatkan produktivitas ternak kambing guna memenuhi 
kebutuhan daging (protein) yang dapat meningkatkan kesejahteraan masyarakat, maka perlu dilakukan beberapa upaya diantaranya dengan menyilangkan kambing lokal atau yang sudah ada di masyarakat dengan kambing yang memiliki produktivitas yang lebih baik.

Kambing Saburai merupakan produk unggulan dari Kabupaten Tanggamus Propinsi Lampung, kambing Saburai adalah kambing hasil persilangan antara kambing $\mathrm{PE}$ betina dengan pejantan kambing Boer. Berdasarkan SK Menteri Pertanian No 359/Kpts/PK.040/6/2015 tanggal 8 Juni 2015 kambing Saburai telah ditetapkan sebagai salah satu plasma nutfah Indonesia yang harus dijaga, ditingkatkan dan dikembangkan populasinya sehingga dapat memberi banyak manfaat bagi peternak dan juga dalam upaya mencukupi kebutuhan daging, baik tingkat lokal dan nasional (Adhianto et al., 2016).

Kambing Saburai dikembangkan di Kecamatan Gisting dan Kecamatan Sumberejo yang telah di persiapkan oleh pemerintah daerah sebagai wilayah sumber bibit kambing Saburai. Kambing Saburai saat ini telah banyak dikembangkan dan menjadi salah satu komoditi ternak unggulan Provinsi Lampung. Perkembangan kambing Saburai yang pesat tersebut berkaitan erat dengan potensi Provinsi Lampung yang besar dalam penyediaan pakan ternak, baik hijauan maupun limbah pertanian, perkebunan, dan agroindustri (Dinas Peternakan dan Kesehatan Hewan Provinsi Lampung, 2015).

Kambing Saburai memiliki keunggulan berupa pertumbuhan yang pesat, produksi daging yang tinggi, mampu beradaptasi dengan lingkungan yang panas, dan memiliki tingkat kesuburan yang tinggi. Pengembangan kambing Saburai perlu dilakukan untuk mempertahankan populasi serta produktifitas kambing Saburai. Pengembangan kambing Saburai dapat ditempuh melalui perbaikan mutu genetik dan perbaikan lingkungan. Salah satu cara yang dapat dilakukan dalam peningkatan mutu genetik serta produktivitas ternak adalah melalui program Village Breeding Centre (VBC) seperti yang telah dilakukan di Kabupaten Tanggamus. Kegiatan VBC yang dilakukan salah satunya meliputi seleksi betina atau indukan unggul untuk meningkatkan produktivitas ternak tersebut.

Hasil penelitian ini diharapkan dapat memberikan informasi kepada peternak mengenai kinerja kambing Saburai yang dipelihara dan dapat digunakan untuk meningkatkan produktivitasnya.

\section{MATERI DAN METODE}

\section{Waktu dan Tempat}

Penelitian ini dilaksanakan pada Juni sampai dengan Agustus 2019 di kelompok peternak kambing Saburai Tani Makmur II Desa Gisting Atas, Kecamatan Gisting, Kabupaten Tanggamus, Lampung.

\section{Materi}

Alat yang digunakan dalam penelitian ini adalah alat tulis, kamera, dan kuisioner, sedangkan bahan yang digunakan dalam penelitian ini adalah recording (buku catatan), kambing Saburai pada berbagai tingkatan umur, baik induk, cempe maupun kambing muda yang dipelihara peternak dan melibatkan 14 orang peternak sebagai responden.

\section{Metode Percobaan}

Penelitian ini merupakan studi kasus kinerja kambing Saburai berlokasi di Desa Gisting Atas, Kecamatan Gisting, Kabupaten Tanggamus, Lampung. Data yang digunakan dalam penelitian ini terdiri dari data primer dan data sekunder. Data primer diperoleh melalui wawancara dengan peternak dan pengamatan langsung di lapangan. Wawancara dilakukan dengan memberikan pertanyaan dengan bantuan kuisioner pada peternak kambing Saburai yang meliputi pengambilan data profil peternak. Data sekunder diperoleh melalui recording milik peternak. Data kinerja ternak diamati dengan menggunakan kartu catatan ternak (recording).

Data profil peternak terdiri atas umur peternak, mata pencaharian, pendidikan, komposisi dan kepemilikan ternak, tujuan beternak, tujuan produksi serta tipe kandang yang digunakan. Data kinerja meliputi, litter size, post partum estrus, post partum mating, interval kelahiran, bobot lahir, bobot sapih, dan bobot umur 1 tahun.

\section{Analisis Data \\ Data dianalisis secara deskriptif.}

\section{HASIL DAN PEMBAHASAN}

\section{Profil Peternak Kambing Saburai}

Profil peternak di kelompok peternak kambing Saburai Tani Makmur II yang berlokasi di Desa Gisting Atas, Kecamatan Gisting, Kabupaten Tanggamus, Lampung, berdasarkan pengamatan di lapangan dan wawancara dengan peternak, dapat dilihat pada Tabel 1. 
Tabel 1. Profil peternak kambing Saburai

\begin{tabular}{lc}
\hline \multicolumn{1}{c}{ Parameter } & Rata-rata \\
\hline Jumlah Peternak (orang) & 14,00 \\
Umur Peternak (tahun) & 44,57 \\
Mata Pencaharian utama (\%) & \\
Petani & 64,29 \\
Peternak & 35,71 \\
Pendidikan (\%) & \\
Tamat SD & 57,14 \\
Tamat SMP & 28,57 \\
Tamat SMA & 14,29 \\
Lama Beternak (Tahun) & 5,50 \\
Tujuan Pemeliharaan (\%) & \\
Tabungan & 0,00 \\
Menambah Pendapatan & 100,00 \\
Kepemilikan Ternak (ekor) & 10,00 \\
Jumlah Ternak \% & \\
0-6 ( bulan) & 21,28 \\
6-12 ( bulan) & 24,82 \\
>12 ( bulan) & 53,90 \\
Tipe Kandang (\%) & \\
Panggung & 100,00 \\
Lantai & 0,00 \\
Sistem Pemeliharaan (\%) & \\
Intensif & 100,00 \\
Semi Intensif & 0,00 \\
Ekstensif & 0,00 \\
\hline
\end{tabular}

Tabel 1 menunjukkan bahwa jumlah peternak kambing Saburai pada kelompok Tani Makmur II di Desa Gisting Atas Kecamatan Gisting Kabupaten Tanggamus sebanyak 14 orang. Rata-rata umur peternak yaitu 44,57 tahun dengan umur termuda yaitu 32 tahun dan umur tertua 55 tahun. Hal ini menunjukkan bahwa peternak masih berada dalam kisaran umur produktif. Umur peternak diduga berpengaruh terhadap mobilitas peternak dalam memelihara ternaknya, semakin muda maka akan semakin gesit, sehingga diharapkan dengan umur muda dan produktif peternak akan mampu memelihara ternaknya dengan baik dan produktivitas ternak akan meningkat.

Sebagian besar peternak bermata pencaharian utama sebagai petani $(64,29 \%)$ dan selebihnya $(35,71 \%)$ menjadi peternak sebagai mata pencaharian utama. Berdasarkan hasil tersebut peternak lebih banyak bermata pencaharian utama sebagai petani dan menjadikan ternak sebagai mata pencaharian sampingan. Semua peternak menyatakan bahwa tujuan pemeliharaan ternak kambing untuk menambah pendapatan. Hasil penelitian Budisatria (2006) menyatakan bahwa ternak kambing belum layak digunakan sebagai mata pencaharian pokok dan masih dianggap sebagai usaha sampingan dan tabungan yang sewaktuwaktu bisa dijual apabila peternak membutuhkan uang mendadak.

Pengalaman peternak dalam beternak kambing Saburai terbilang cukup matang dengan rata-rata pengalaman beternak selama 5,5 tahun. Hal ini disebabkan pada 2015 kambing Saburai telah ditetapkan sebagai salah satu plasma nutfah Indonesia yang harus dijaga, ditingkatkan dan dikembangkan populasinya sehingga dapat memberi banyak manfaat.

Mayoritas tingkat pendidikan terakhir peternak adalah SD sebanyak 57,14\%, sedangkan yang berpendidikan SMP sebanyak 28,57\% dan SMA sebesar 14,29\%. Hasil penelitian ini masih lebih baik dibandingkan dengan hasil penelitian Murdjito et al. (2011) yang menyatakan bahwa mayoritas tingkat pendidikan terakhir peternak adalah SD (37,5\%), bahkan peternak yang tidak pernah mengenyam pendidikan formal juga masih tinggi (16,7\%), sedangkan yang berpendidikan SMP sebesar 29,3\% dan SMA 12,5\%. Tingkat pendidikan peternak merupakan salah satu faktor yang akan melancarkan program penyuluhan yang dilakukan oleh Dinas Peternakan setempat. Tingkat pendidikan yang relatif rendah dapat berpengaruh terhadap manajemen ternak.

Rata-rata jumlah kepemilikan ternak kambing Saburai yang dimiliki oleh peternak di Desa Gisting Atas yaitu 10 ekor. Struktur populasi terbesar adalah umur lebih dari 12 bulan $(53,90 \%)$, diikuti umur 6--12 bulan $(24,82 \%)$, dan umur kurang dari 6 bulan $(21,28 \%)$. Hal ini dapat dipahami karena tujuan sistem pemeliharaan adalah bibit atau menghasilkan anakan, sehingga komposisi terbesar adalah induk dan cempe.

Tipe kandang yang digunakan yaitu tipe kandang panggung. Kelebihan kandang panggung yaitu kandang relatif lebih bersih karena kotoran dan air kencing jatuh kebawah, lantai kandang lebih kering dan tidak becek, kuman penyakit, parasit dan jamur yang hidup di lantai kandang dapat ditekan perkembangannya. Kelemahan dari kandang panggung yaitu biaya pembuatannya relatif mahal, resiko kecelakaan karena ternak terperosok atau jatuh lebih besar, hal ini dikarenakan kandang memikul beban berat dari ternak yang ada di atasnya (Ludgate, 2006).

Peternak di Desa Gisting Atas menerapkan sistem pemeliharaan intensif. Menurut Williamson dan Payne (1993), sistem pemeliharaan secara intensif memerlukan pengandangan terus menerus atau tanpa penggembalaan, sistem ini dapat mengontrol dari faktor lingkungan yang tidak baik dan 
mengontrol aspek-aspek kebiasaan kambing yang merusak. Namun, kelemahan sistem pemeliharaan intensif yaitu biaya produksi dan tenaga yang dikeluarkan lebih banyak, peternak harus rutin membersihkan kotoran ternak, peternak harus menyediakan pakan dan juga minum ternak.

\section{Kinerja Kambing Saburai}

Hasil penelitian kinerja kambing Saburai di Kabupaten Tanggamus yang meliputi interval kelahiran, litter size, post partum estrus, post partum mating, bobot lahir, bobot sapih, dan bobot 1 tahun dapat dilihat pada Tabel 2 .

Tabel 2. Kinerja kambing Saburai

\begin{tabular}{lc}
\hline \multicolumn{1}{c}{ Parameter } & Rata-rata \\
\hline Interval Kelahiran (hari) & $310,43 \pm 49,70$ \\
Litter Size (ekor) & $1,88 \pm 0,40$ \\
Post Partum Estrus (hari) & $61,58 \pm 9,72$ \\
Post Partum Mating (hari) & $149,11 \pm 51,19$ \\
Bobot Induk (kg) & $35,65 \pm 2,74$ \\
Bobot Lahir (kg) & $2,83 \pm 0,11$ \\
Bobot Sapih (kg) & $11,28 \pm 1,36$ \\
Bobot 1 Tahun (kg) & $25,98 \pm 2,93$ \\
\hline
\end{tabular}

Tabel 2 menunjukkan bahwa rata-rata interval kelahiran kambing Saburai di Kabupaten Tanggamus yaitu $310,43 \pm 49,70$ hari atau $10,35 \pm 1,66$ bulan. Hal ini menunjukkan bahwa interval kelahiran pada kambing Saburai lebih lama dibandingkan dengan kambing Bligon dan kambing Saburai yang pernah diteliti sebelumnya. Adhianto et al. (2016) menyatakan bahwa interval kelahiran kambing Saburai di Desa Campang sebesar 249 $\pm 1,04$ hari. Murdjito et al. (2011) menyatakan bahwa rata-rata interval kelahiran induk kambing Bligon (hasil persilangan antara kambing PE dan kambing Kacang) adalah $8,53 \pm 1,93$ bulan. Interval kelahiran yang lebih lama pada kambing Saburai diduga akibat kurang memperhatikan siklus estrus pada ternak atau keterbatasan waktu yang dimiliki peternak, sehingga menyebabkan proses perkawinan menjadi lebih lama.

Lama interval kelahiran dapat memengaruhi produktivitas ternak tersebut. Menurut Devendra dan Burns (1994), jarak beranak merupakan faktor yang sangat menentukan tinggi rendahnya rata-rata produksi anak yang dihasilkan pertahun, semakin pendek jarak beranak, maka semakin tinggi hasil produksi yang diperoleh. Beberapa faktor yang memengaruhi panjang pendeknya jarak beranak antara lain adalah bangsa, umur kambing, frekuensi beranak, kandungan nutrisi ransum, dan service per conception.

Hasil penelitian litter size pada kambing Saburai di Desa Gisting Atas menunjukkan nilai $1,88 \pm 0,40$ ekor. Hasil tersebut menunjukkan bahwa litter size kambing Saburai lebih tinggi dibandingkan dengan penelitian yang dilakukan oleh Adhianto et al. (2016) bahwa rata-rata litter size kambing Saburai di Desa Campang sebesar 1,53 $\pm 0,60$ ekor. Hasil ini juga lebih tinggi dibandingkan dengan kambing PE dan kambing Bligon. Badriyah et al. (2011) melaporkan bahwa rata-rata litter size kambing PE 1,83 $\pm 0,56$ ekor dan Murdjito et al. (2011) menyatakan bahwa rata-rata litter size kambing Bligon yaitu $1,74 \pm 0,45$ ekor. Litter size yang lebih tinggi disebabkan karena peternak sudah mulai melakukan seleksi terhadap induk yang memiliki litter size tinggi. Dalam kondisi normal, persentase kelahiran mencapai $95 \%$ dimana sekitar 7--15\% dari kambing betina dapat melahirkan 3 anak dan lebih dari 50\% dapat melahirkan 2 anak (Barry dan Godke, 1991). Penelitian ini dilakukan saat musim kemarau sehingga diduga memengaruhi kandungan nutrisi hijauan dan berdampak pada rendahnya bobot ternak. Bobot ternak yang rendah dapat memengaruhi litter size. Sodiq et al. (2003) menyatakan bahwa litter size dipengaruhi oleh beberapa faktor antara lain bangsa, genetik, umur induk waktu beranak, berat badan induk, pengaruh pejantan, musim, dan tingkat nutrisi.

Post partum estrus digunakan untuk mengetahui estrus atau birahi pada ternak betina setelah melahirkan. Hasil penelitian post partum estrus pada kambing Saburai yaitu 61,58 $\pm 9,72$ hari. Berdasarkan penelitian tersebut post partum estrus pada kambing Saburai di Desa Gisting Atas lebih lama dibandingkan hasil penelitian Adhianto et al. (2016) bahwa post partum estrus kambing Saburai di Desa Campang sebesar 53 $\pm 20,13$ hari. Namun, lebih cepat dibandingkan kambing Bligon. Menurut Murdjito et al. (2011), rata-rata post partum estrus kambing Bligon yaitu $63,16 \pm 30,56$ hari. Post partum estrus merupakan faktor penting yang memengaruhi efisiensi reproduksi pada kambing. Semakin pendek selang birahi pertama setelah beranak, akan semakin pendek selang beranak, dan sebaliknya.

Post partum mating merupakan salah satu faktor penentu panjangnya interval beranak. Hasil penelitian post partum mating pada kambing Saburai yaitu $149,11 \pm 51,19$ hari. Penelitian ini menunjukkan bahwa post partum mating pada kambing Saburai lebih lama dibandingkan dengan hasil penelitian yang dilakukan oleh Adhianto et al. (2016) bahwa post 
partum mating kambing Saburai di Desa

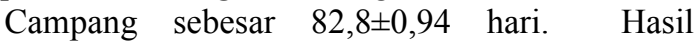
penelitian post partum mating pada kambing Saburai masih berada dalam kisaran normal, hal ini sesuai dengan pendapat Murdjito et al. (2011) yang menyatakan bahwa rata-rata post partum mating kambing Bligon yaitu kisaran 45--180 hari. Devendra dan Burns (1994) menambahkan bahwa kawin pertama setelah beranak baru timbul setelah kurang lebih tujuh bulan.

Panjang pendeknya post partum mating secara mendasar dipengaruhi oleh dua pertimbangan utama, yaitu pertimbangan fisiologis dan ekonomi. Secara fisiologi post partum mating memberi kesempatan berlangsungnya involusi uterus atau pemulihan kondisi organ reproduksi induk setelah melahirkan sampai induk siap kembali untuk proses reproduksi selanjutnya. Pertimbangan ekonomis dilakukan berdasarkan pengaruh post partum mating terhadap tingkat konsepsi, kebuntingan, efisiensi tenaga kerja dan produktivitas susu induk (Noor, 2011).

Hasil yang diperoleh dari bobot induk kambing Saburai sebesar 35,65 2,74 kg. Hal ini menunjukkan bahwa bobot induk dalam kisaran normal. Berdasarkan surat keputusan Menteri Pertanian Republik Indonesia Nomor395/kpts/PK.040/6/2015, bobot tubuh kambing Saburai betina dewasa sebesar 33,81+ $6,12 \mathrm{~kg}$. Pertambahan bobot badan dipengaruhi oleh beberapa faktor yaitu genetik, lingkungan antara lain nutrisi dan manajemen pemeliharaan, serta faktor internal antara lain jenis kelamin dan umur (National Research Council, 1985).

Bobot lahir merupakan salah satu faktor penting di dalam dunia peternakan karena bobot tersebut merupakan titik awal pengukuran perkembangan selanjutnya. Hasil penelitian yang terdapat pada Tabel 2 menunjukkan bahwa bobot lahir pada kambing Saburai yaitu $2,83 \pm 0,11 \mathrm{~kg}$. Hasil tersebut menunjukkan bahwa bobot lahir kambing Saburai lebih kecil dibandingkan hasil penelitian kambing Saburai terdahulu. Adhianto et al. (2016) menyatakan bahwa bobot lahir kambing Saburai di Desa Campang sebesar $3,05 \pm 0,23 \mathrm{~kg}$. Bobot lahir yang lebih rendah ini diduga akibat induk yang unggul banyak terjual ke konsumen luar Kabupaten Tanggamus, sehingga tidak ada atau sedikit bibit baru yang unggul.

Bobot sapih merupakan indikator kemampuan induk dalam menghasilkan susu dan kemampuan anak kambing untuk mendapatkan susu dan tumbuh. Bobot sapih merupakan hasil penimbangan anak kambing saat dipisahkan pemeliharaanya dari induknya. Bobot sapih kambing Saburai pada penelitian ini yaitu
$11,28 \pm 1,36 \mathrm{~kg}$. Bobot sapih tersebut lebih rendah dibandingkan dengan hasil penelitian Adhianto et al. (2016) yang menyatakan bahwa bobot sapih kambing Saburai di Desa Campang sebesar 16,76 $\pm 1,64 \mathrm{~kg}$. Bobot sapih lebih rendah dari penelitian sebelumnya, diakibatkan oleh litter size yang diperoleh lebih tinggi dari penelitian Adhianto et al. (2016). Semakin tinggi litter size ternak maka semakin rendah bobot lahir dan bobot sapih yang dihasilkan dan sebaliknya.

Tabel 2 menunjukkan bahwa bobot 1 tahun pada kambing Saburai di Desa Gisting Atas yaitu $25,98 \pm 2,93 \mathrm{~kg}$. Hasil tersebut lebih rendah dibandingkan dengan kambing PE umur 1 tahun. Sulastri dan Qisthon (2007) menyatakan bahwa bobot badan kambing PE pada umur satu tahun hanya mencapai $28 \mathrm{~kg}$. Hasil penelitian ini juga menunjukkan bahwa bobot kambing Saburai umur 1 tahun lebih rendah dibandingkan penelitian tahun-tahun sebelumnya. Adhianto et al. (2016) menyatakan bahwa bobot kambing Saburai umur 1 tahun di Desa Campang yaitu 43,67 $\pm 5,51 \mathrm{~kg}$. Menurut Faruque et al. (2010), performa pertumbuhan kambing pada umur 1 tahun merupakan ekspresi potensi genetik individu sendiri dan sudah tidak dipengaruhi oleh induk karena sudah lepas sapih dan tidak dirawat oleh induknya.

Rendahnya bobot 1 tahun pada kambing Saburai diduga karena berawal dari bobot lahir dan bobot sapih yang rendah serta kurangnya nutrisi dalam kandungan pakan yang diberikan. Selain itu, rata-rata peternak beternak kambing Saburai sebagai mata pencaharian tambahan sehingga diduga proses manajemen pemeliharaan kurang maksimal dan mengakibatkan bobot tubuh kambing Saburai rendah.

\section{KESIMPULAN}

Berdasarkan hasil penelitian ini dapat disimpulkan bahwa kinerja kambing Saburai yang dipelihara peternak mengalami penurunan bila dibandingkan dengan tahun-tahun sebelumnya.

\section{DAFTAR PUSTAKA}

Adhianto, K., M. D. I. Hamdani., Sulastri, dan I. Listiana. 2016. Performa produksi kambing Saburai jantan pada dua wilayah sumber bibit di Kabupaten Tanggamus. Sains Peternakan 14(2): 22--29.

Adhianto, K., Sulastri, dan Siswanto. 2016. Performa Kambing Saburai yang 
dipelihara Peternak di Desa Campang Kecamatan Gisting Tanggamus. Universitas Lampung. Bandang Lampung.

Badan Pusat Statistik. 2013. Proyeksi Penduduk Indonesia 2010--2035. Badan Pusat Statistik. Jakarta.

Badriyah, T., Susilawati, dan S. Wahyuningsih. 2011. Perbedaan Produktifitas Kambing Peranakan Ettawah (PE) antara Perkawinan Alam dan Perkawinan Inseminasi Buatan (IB) di Ampel Gading Kabupaten Malang. Tesis. Universitas Brawijaya. Malang.

Barry, D .M. dan R. A. Godke. 1991. The Potential for Cross. Symp. In: Goat Meat Production and Marketing. Oklahama. USA.

Budisatria, I. G. S. 2006. Dynamics of Small Ruminant Development in Central Java Indonesia. Tesis. Wageningen Agriculture University. Wageningen, The Netherlands.

Devendra, C. dan M. Burns. 1994. Produksi Kambing di Daerah Tropis. Universitas Udayana Press. Bandung.

Dinas Peternakan dan Kesehatan Hewan Provinsi Lampung. 2015. Proposal

Penetapan Rumpun Kambing Saburai. Dinas Peternakan dan Kesehatan

Hewan Provinsi Lampung. Bandar Lampung.

Faruque, S., S. A. Chowdhury., N. U. Siddiquee, and M. A. Afroz. 2010. Performance and genetic parameters of economically important traits of Black Bengal goat. J. Bangladesh Agr. 8(1): 67--78.

Kementerian Pertanian Republik Indonesia. 2015. Keputusan Menteri Pertanian Republik Indonesia. Nomor : 359/kpts/PK.040/6/2015. Tentang Penetapan Rumpun Kambing Saburai.
Kementerian Pertanian Republik Indonesia. Jakarta.

Ludgate, P. J. 2006. Sukses Beternak Kambing dan Domba. Papas Sinar Sinanti. Jakarta.

Murdjito, G., I. G. S. Budisatria., Panjono., N. Ngadiyono, dan E. Baliarti. 2011. Kinerja kambing Bligon yang dipelihara peternak di desa Giri Sekar Panggang Gunungkidul. Buletin Peternakan. 35(2): 86--95.

National Research Council. 1985. Nutrient Requirement of Sheep 6th. Revised UniEdition. National Academy Press. Washigton.

Noor, A. E. O. 2011. Manajemen Reproduksi pada Usaha Peternakan Sapi Perah di Kabupaten Enrekang. Skripsi. Fakultas Peternakan Universitas Hasannudin. Makassar.

Sodiq, A., S. Adjisoedarmo, dan E.S. Tawfik. 2003. Reproduction Rate of Kacang Peranakan Ettawa Goats under Village Production Systems in Indonesia. International Research on Food Security, Natural Resource Management and Rural Development Technological and Instutional Innovations for Substainable Rular Development. Deutscher Tropentag Gottaingen.

Sulastri. dan A. Qisthon. 2007. Nilai Pemuliaan Sifat-Sifat Pertumbuhan Kambing Boerawa Grade 1--4 pada Tahapan Grading up Kambing Peranakan Etawah Betina oleh Jantan Boer. Laporan Penelitian Hibah Bersaing. Universitas Lampung. Bandar lampung.

Williamson, G. dan W. J. A. Payne. 1993. Pengantar Peternakan di Daerah Tropis. Universitas Gadjah Mada Press. Yogyakarta. 